\title{
Change Detection of Urban Growth in Some Area in El-Gharbiya Governorate Using Remote Sensing and GIS Techniques.
}

Nagwa F. M. EL-Fekey ${ }^{1}$, Heba S. A. Rashed ${ }^{1}$, Fahmy M. Habib ${ }^{1}$ and Abdel-Aziz A. Belal ${ }^{2}$

ISoil and Water Department, Faculty of Agriculture, Moshtohor, Benha University, Egypt 2National Authority for remote sensing and Space Science, (NARSS), Cairo, Egypt.

\begin{abstract}
Urban spraw1 is one of the main problems that led to the reduction of the limited fertile land in the Nile Delta in Egypt. Now in Egypt, it may cause problems in food security. Remote sensing and GIS are effective tools to map and analyze urban sprawl using three Land sat images (Land sat-TM acquired in 1986, Land sat$\mathrm{ETM}^{+}$acquired in 2013 and Landsat-OLI acquired in 2019), which provide needed data for measuring the change in urban area for the studied area. The purpose of this study is to estimate the changes in Agriculture area due to urban sprawl in El-Gharbiya Governorate, Egypt by using remotely sensed Land sat multispectral images for the period between the years 1986 to 2019. Software's (ENVI 5.1 and ArcGIS 10.2) have been used for processing and analyzing remote sensing data. Satellite data monitoring of land use -land cover changes in the study area. There were two classes identified in the studied area in 1986 and 2019, the agricultural area and urban sprawl. Area of agriculture land decreasing by 6000 ha. Urban area increasing by 5880 ha. The changing patterns of human life, human activities and increasing population growth in the study area have accelerated the environmental degradation. Urban expansion is the land degradation process in the study area. Agriculture, which present the first and largest economic sectors in the study area need to get more attention from the Government because these are most influenced and damaged sectors by urban encroachment. The application of law in Egypt must be enhanced and the essential services must be provided for the increase in the development of rural areas.
\end{abstract}

\section{Introduction}

Egypt's agriculture is the core of the national economy and the soils in the Nile Delta is most suitable for Egyptian agriculture. Only approximately $4 \%$ of Egypt's total area are agricultural land. The remaining $96 \%$ of the land is arid desert. Seen from this perspective, the need for reclamation of the desert appears inevitable in light of continuing population growth and increasing congestion in the long-settled lands in the Nile valley and the delta (Hamdi and Abdelhafez,2001). The government also aims to transfer the driving force of agricultural land away from the old and high-yielding agricultural land in the Nile Delta through effective horizontal urban expansion and the reclamation of more desert areas and land near the edge of the Nile Delta. Bella et al., 2014). Arable land in the Nile Delta is 1.85 million hectares that represent $51.2 \%$ of the total cultivated land, and $73.3 \%$ of the old fertile alluvial soils in Egypt. This region houses half of Egypt's inhabitants and about two thirds of the agricultural activities (Mohamed, 2017a). Fertile lands in this region undergo degradation processes including salinization , sodification, water logging, compaction (Abdel Rahman et al., 2017), chemical and physical risks (El-Baroudy and Moghanm, 2014), and water erosion due to Mediterranean Sea level rise, along the promontories of the Rosetta and Damietta branches (Embabi, 2018).

In Egypt, the management of different natural resources (land and water) is necessary to maintain food supply and achieve the sustainability of agricultural development; however, unfortunately, natural resources are under severe pressure from increasing population and continuing land degradation (El-Baroudy et al., 2011).

Urban growth has led to changes in land use /land cover in many parts of the world, especially in developing countries. Egypt's unprecedented population growth coupled with unplanned development activities has led to the destruction of agricultural land. Change detection is the process of identifying differences in states by observing objects or phenomena remotely at different times. The changes caused by human forces are the result of humans changing the environment (Pilon et al., 1988). Change detection has become the main application of remote sensing data. Satellite remote sensing is a potentially powerful means to monitor land use changes with high time resolution and at a lower cost than using traditional methods (Jensen, 1983; Martin, 1986; Martin and Howarth, 1989 and El-Raey et al., 1995). Land degradation and urban expansion are the most common problems that threaten ongoing agricultural activities and prohibit further reclamation expansion (A Mohamed E.S et al., 2011; and Mohamed et al., 2013). During and after the Egyptian Revolution that began on January 25, 2011, urban sprawl on agricultural land was one of the negative results due to the lack of a security system. During this period, the monitoring report issued by the Agricultural Land Protection Bureau (DLPDA) of Egypt's El-Gharbia Province showed that there was a lot of evidence of urban encroachment on the agricultural center.

Soil degradation has become an important factor that seriously threatens food production, reduces agricultural income, slows economic development, increases water siltation, changes the earth's carbon 
storage, weakens watershed functions, and brings structural and functional disorders to the entire terrestrial ecosystem (Weinzier et al, 2015 and Hazbavi et al., 2019). The causes of land degradation in tropical areas are the complex relationships of climatic conditions, steep slopes, poor agricultural practices, high risk of soil erosion, overpopulation, lack of appropriate policies, and over-reliance on subsistence crop cultivation (Sanchez et al., 2003).Increased farm degradation in the area has led to increased nutrient requirements for crop production (Ngome et al., 2011 and Tittonell et al., 2007). Land degradation (LD) is a temporary or permanent decline in the productive capacity and quality of land, leading to a decline in its ecological and economic functions. This is one of the biggest challenges in the world, especially for developing countries in Asia and Africa (Mahala, 2017). Land degradation is not only one of the most serious environmental problems in the world, but also one of the major social and economic problems. Food and energy security (Reed et al., 2011), land desertification (Salih et al., 2017. Liu et al., 2008), sustainable socio-economic system development and human living environment (Winslow et al., 2011). Land degradation has become one of the biggest challenges facing mankind in the world today (Velmourougane and Blaise, 2017). Because human activities exaggerate natural events, land degradation is often described as a significant decline in the biological productivity of the land system (Johnson and Lewis 2007). The United Nations Convention to Combat Desertification
(UNCCD) recognizes that land degradation is one of the most noticeable environmental problems in modern times (UNCCD 1994, 2002). According to Baylis et al, 2012 and UNCCD, 2013, they reported the sequences because of land degradation processes, nearly $40-75 \%$ of the world's agricultural land's productivity is reduced.

Now adays, urban sprawl is an ongoing problem that must be faced in Egypt. It has an impact on our daily life. El-Gharbiya Governorate was taken as a study area to assess the urban sprawl impact on its agricultural land. The aim of the study is to measure the changes in agriculture land resulting from urban encroachment by using remote sensing and GIS techniques.

\section{Materials and Methods}

\subsection{Location of the study area}

The study area is located in the middle of the Nile Delta in the province of El-Gharbiya. It is bounded by Kafr El Shiekh province to the north, El-Monufiya province to the south, El-Dakahlia province to the east, and El-Beheira Governorate to the west. It lies between longitudes $30^{\circ} 45^{\prime} 20^{\prime \prime}-31^{\circ} 10^{\prime} 50^{\prime \prime} \mathrm{E}$ and $30^{\circ} 35^{\prime} 10^{\prime \prime}-31^{\circ} 10^{\prime} 05^{\prime \prime} \mathrm{N}$, with a total area of 192740ha. The detection of land cover/use change in only three areas in El-Gharbiya Province (Basion, Kafr El-zyatand Tanta) from 1986 to 2019 was evaluated through the specification of a multi-time classification joint model.

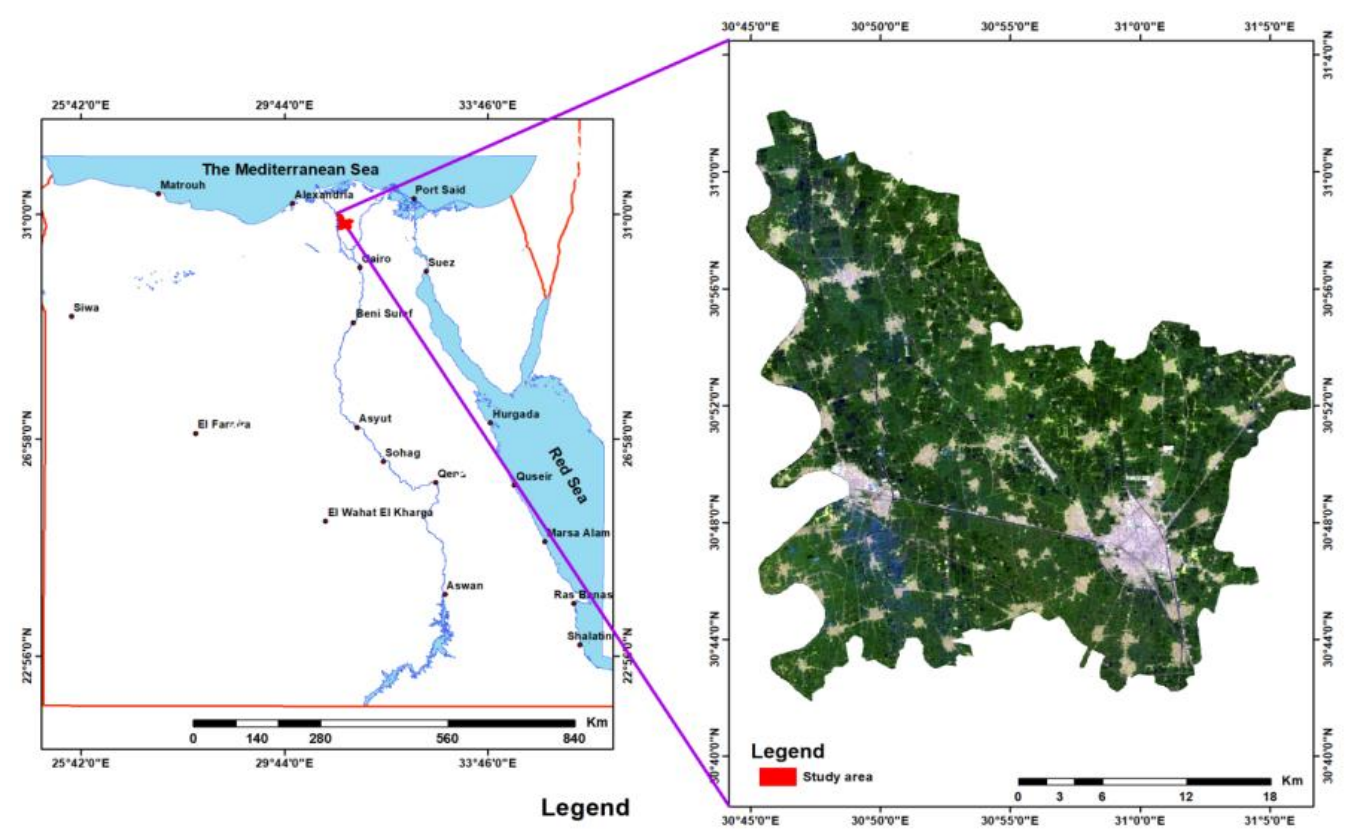

Fig1: Location map o fstudy area

\subsection{Data collection}

Three different types of Landsat imagery (Landsat-TM, Landsat-ETM and Landsat-OLI TIRS) are obtained from the USGS earth explorer website through ENVI version 5.1 and ArcGIS version 10.2. The Landsat-TM image consists of seven spectral bands with wavelengths from $0.45 \mathrm{~m}$ to $2.35 \mathrm{~m}$. The spatial resolution of band 1 to band 5 and band 7 is 30 
$\mathrm{m}$, while the spatial resolution of band 6 (thermal infrared) is $120 \mathrm{~m}$. Landsat-ETM consists of 8 bands with wavelengths ranging from $0.45 \mathrm{~m}$ to $2.35 \mathrm{~m}$. The spatial resolution of bands $1,2,3,4,5$, and 7 is 30 , while bands 6 and 8 are 60 and $15 \mathrm{~m}$, respectively. Land sat OLI TIRS TIRS consists of 11 bands with a spatial resolution of $30 \mathrm{~m}$ in bands $1-7$, band 9 has a spatial resolution of $30 \mathrm{~m}$, bands 10 and 11 (thermal bands) (TIRS) have $100 \mathrm{~m}$, and band 8 The (panchromatic) spatial resolution is $15 \mathrm{~m}$. In order to achieve the research goals, images of three different dates in 1986, 2013 and 2019 were used.

\subsubsection{Post classification change detection}

The images were classified from three time periods (1986, 2013, and 2020) and then compared and detected. Use support vector machine technology to classify each date of the image. Export the classified images to ArcGIS 10.2 software for vectorization, calculation, and area comparison between different dates to identify various changes in land use/land cover increase or decrease. The applied framework of methodology is presented in Figure 2.

Fig.2: Framework of applied methodology

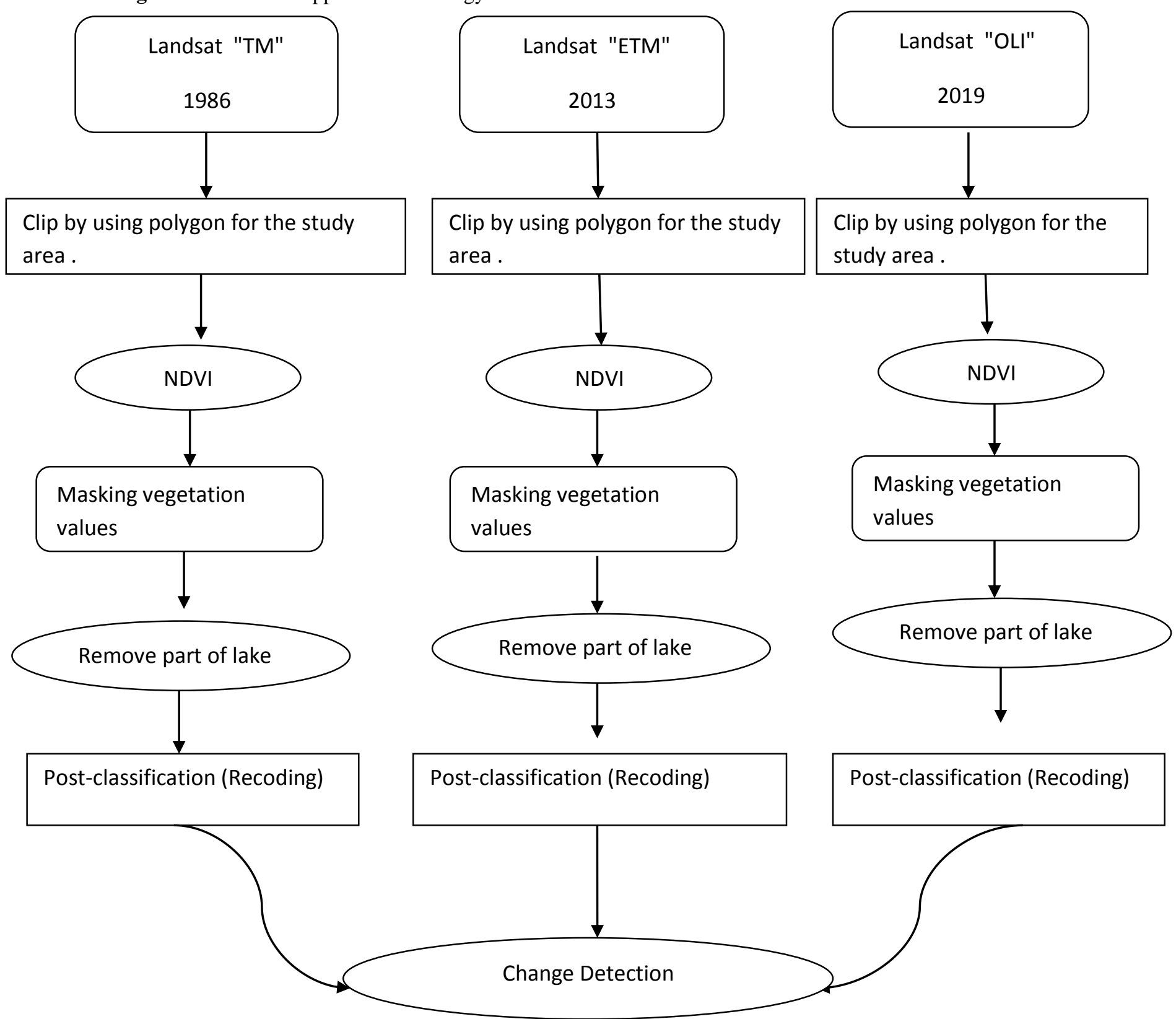

Results and discussion Land use/land cover change detection in the study area.
The obtained classification images, after preprocessing and supervised classification, indicate different land use and land cover patterns in the study area. From 1986 to 2019, changes in different land 
use/land cover types in the study area increased and decreased with changes in different activities such as urban expansion. The main impact of human activities on land degradation in the survey area is urban expansion. The results show that all land use and land cover types change regularly.

Change detection Land use/land cover during the survey period from 1986 to 2013.

Urban growth caused serious losses of agricultural land in Egypt (Hegazy and Kaloop , 2015) Figures3 and 4 show image of Land sat- TM acquired in 1986 and image of Landsat -ETM ${ }^{+}$in 2013 .Urban expansion in El-Gharbiya Governorate during 1986 to 2013 was considerable. The impact of this urban expansion land was evaluated, and the statistical data are illustrate din Table (1) and fig (5). Urban area increased from being 6760 ha in 1986 to 9390 ha in 2013 increasing by 2630 ha. Agricultural area decreased from being 61290 ha in 1986 to 58650 ha in 2013 decreasing by 2640 ha.

Table1.Changes in the areas of different soils and urban In El-Gharbiya Governorate in 1986 and 2013.

\begin{tabular}{cccc}
\hline Land type & Total area in 1986 (ha.) & Total area in 2013 (ha.) & Change area (ha.) \\
\hline Agriculture & 61290 & $\mathbf{5 8 6 5 0}$ & $\mathbf{2 6 4 0}$ \\
Urban & 6760 & 9390 & $\mathbf{2 6 3 0}$ \\
Water & 750 & 750 & 00 \\
Totalarea & 68800 & 68800 & 00 \\
\hline
\end{tabular}

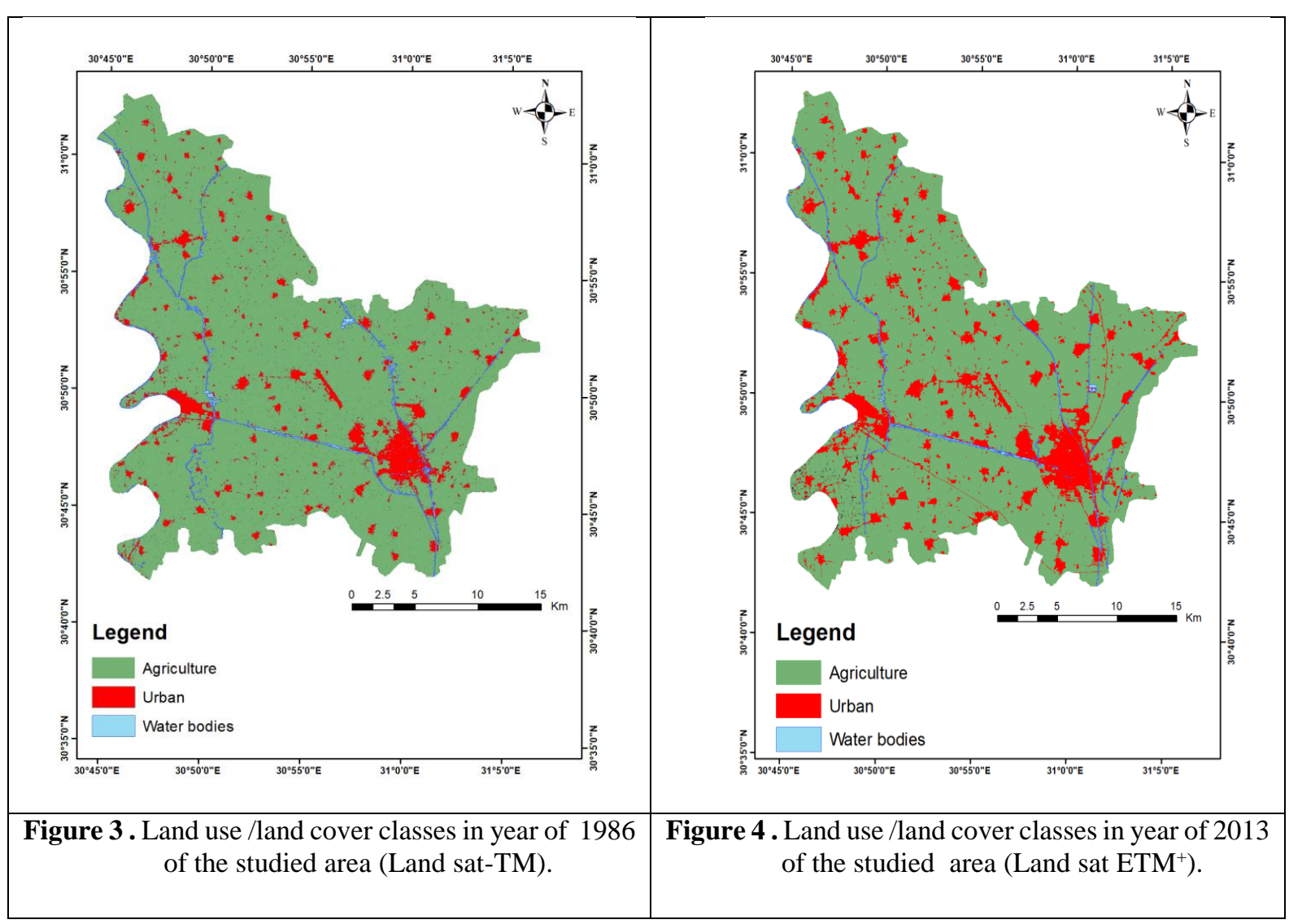




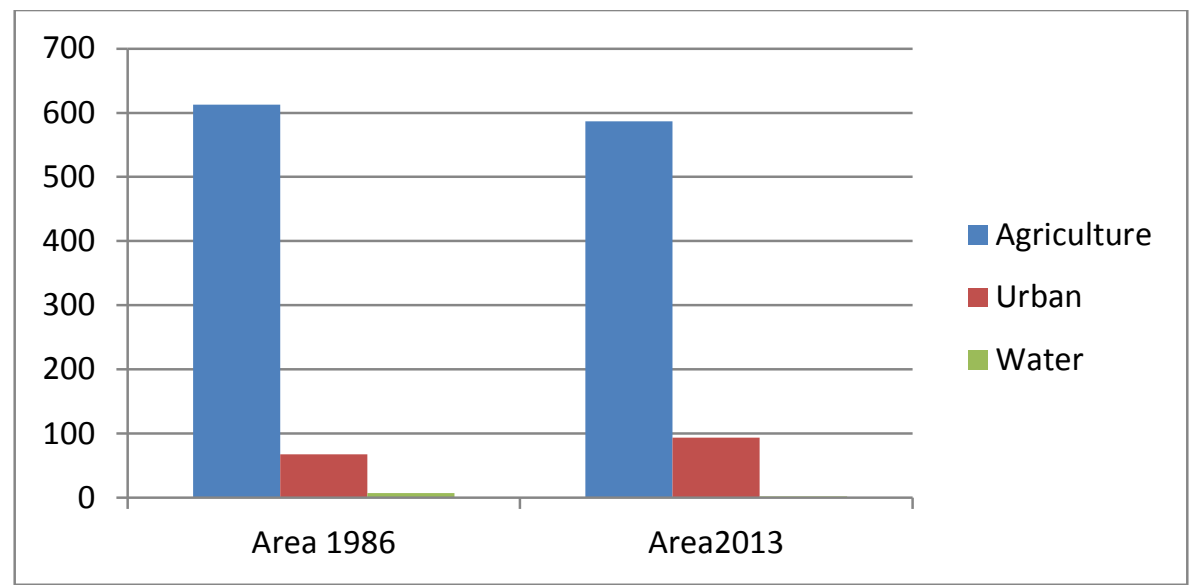

Figure 5. Change detection in agriculture land and urban area during the 1986-2013 in the investing at ed area.

Change detection the land use/land cover of the survey area from 2013 to 2019.

The changes in different characteristics of the survey area from 2013 to 2019 increased or decreased as cities occupied cultivated land and other activities. Figures 6 and 7 show maps of land use/ land cover of Land sat- $\mathrm{ETM}^{+}$acquired in 2013 and image of Land
sat-OLI in 2019. Area of agriculture land increased during the period of 2013 to 2019. In 2013 the 58650ha become 55290 ha in 2018 decreasing by 3360 ha. The area of urban land 9390 ha in 2013 and become 12740 ha in 2020 decreasing by 3350 ha. Table (2) and Figure (8) show the change during the period of 2013 -2019 in El-Gharbiy Governorate.

Table 2. Changes in the areas of different soils and urban In El-Gharbiya Governorate in 2013 and 2019.

\begin{tabular}{cccc}
\hline Land type & Total area in 2013 (ha.) & Total area in 2019 (ha.) & Change area (ha.) \\
\hline Agriculture & 58650 & 55290 & -3360 \\
Urban & 9390 & 12740 & +3350 \\
Water & 760 & 760 & 00 \\
Total area & 688 & 688 & 00 \\
\hline
\end{tabular}

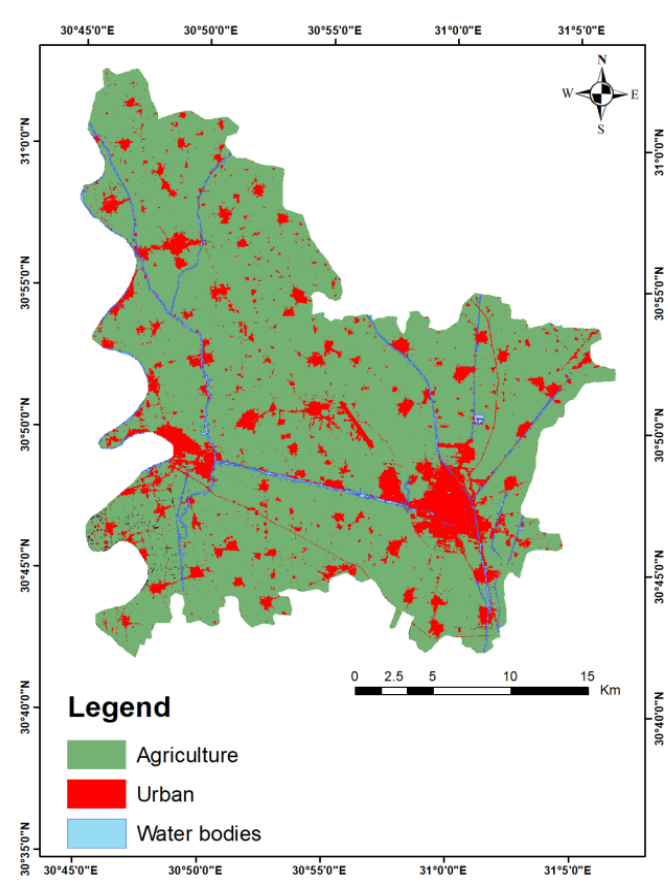

Figure 6. Land use /land cover classes in year of 2013 of the studied area (Land sat $-\mathrm{ETM}^{+}$).

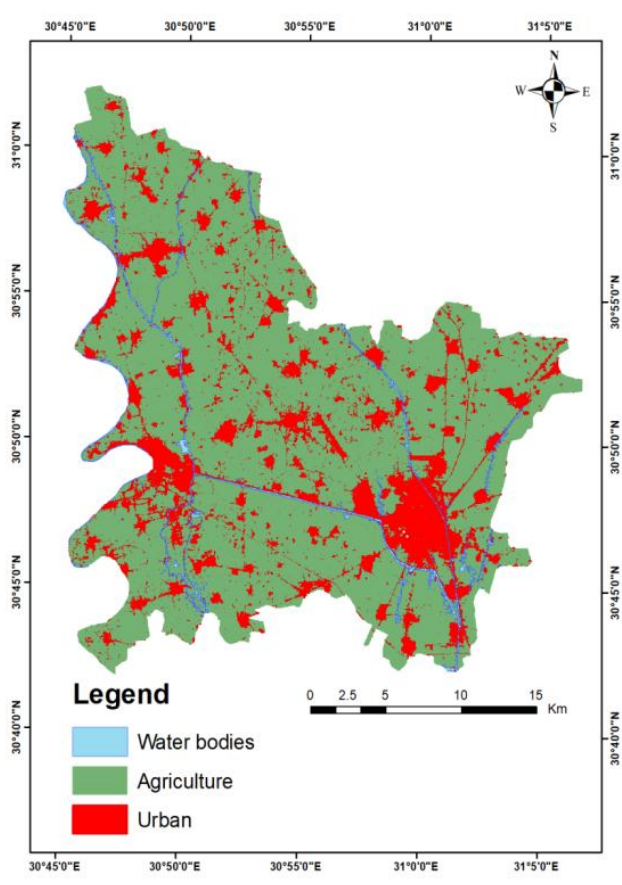

Figure 7. Land use/ land cover classes in year of 2019 of the studied area (Land satOLI). 


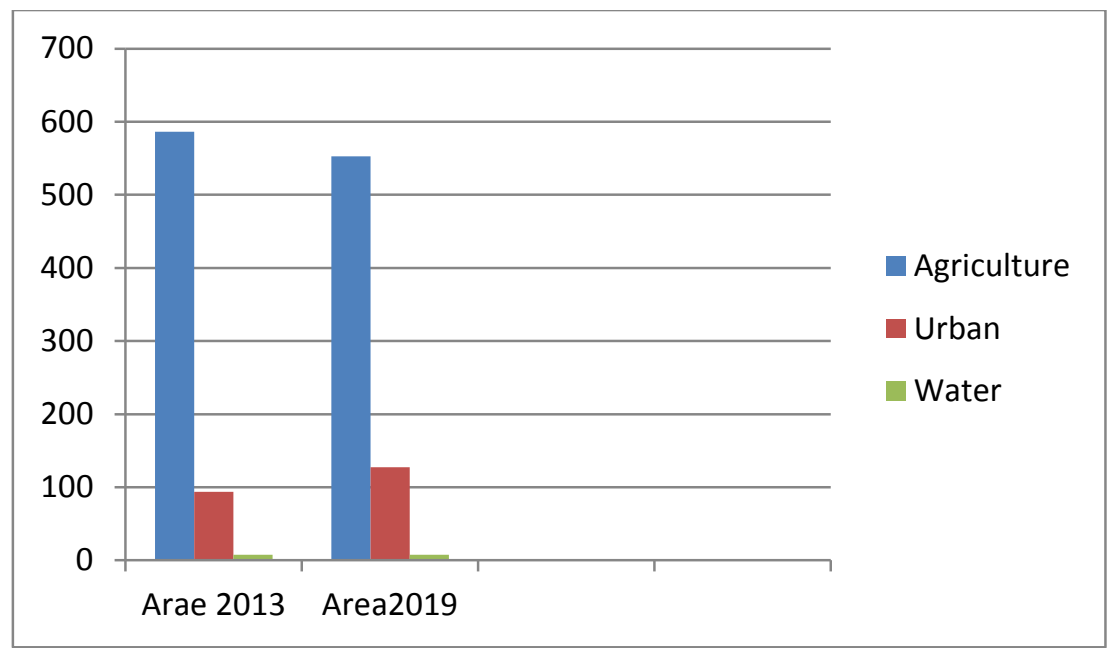

Figure 8. Change detection in agriculture land and urban area during the 2013-2019 In El-Gharbiya Governorate.

Change detection the land use/land cover of the survey area from 1986 to 2019.

Figures 9 and 10 show maps of land use/ land cover of Land sat- TM acquired in 1986 and image of Land satOLI in 2019. Area of agriculture land decreasing during the period of 1986 to 2019. In 1986 the 61290 ha become 55290 ha in 2020 decreasing by 6000 ha. The area of urban land was 6760 ha in 1986 and become 12740 ha in 2020 increasing by 5880 ha. Table 3 and Figure 11 show the change during the period of 1986 -2019 in El-Gharbiya Governorate.

Table 3. Changes in the areas of different soils and urban areas in El-Gharbiya Governorate in 1986 and 2019.

\begin{tabular}{cccc}
\hline Land type & Total area in 1986 (ha.) & Total area in 2019 (ha.) & Change area (ha.) \\
\hline Agriculture & 61290 & 55290 & -6000 \\
Urban & 6760 & 12640 & +5880 \\
Water & 750 & 750 & 00 \\
Total area & 68800 & 68800 & 00 \\
\hline
\end{tabular}

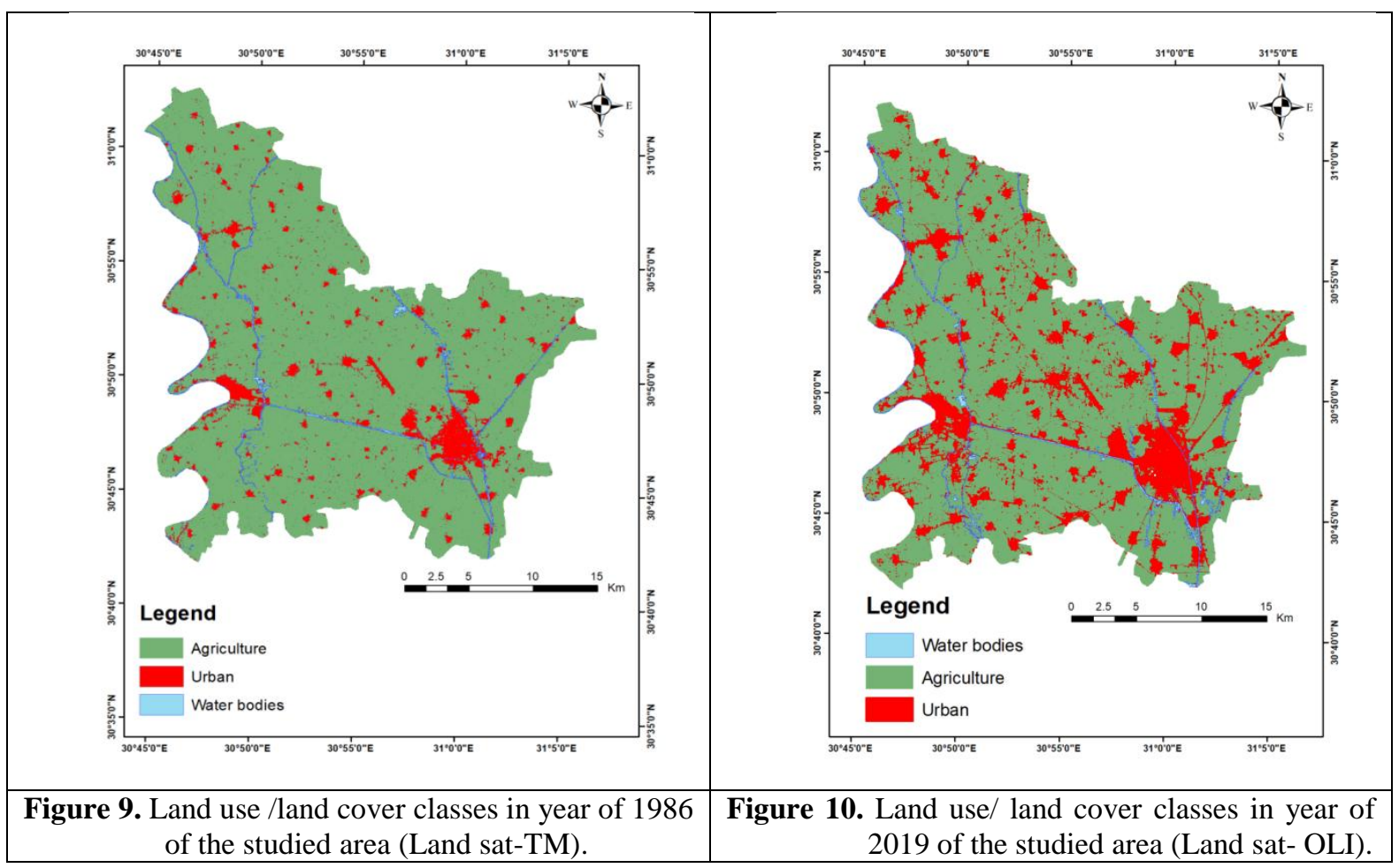




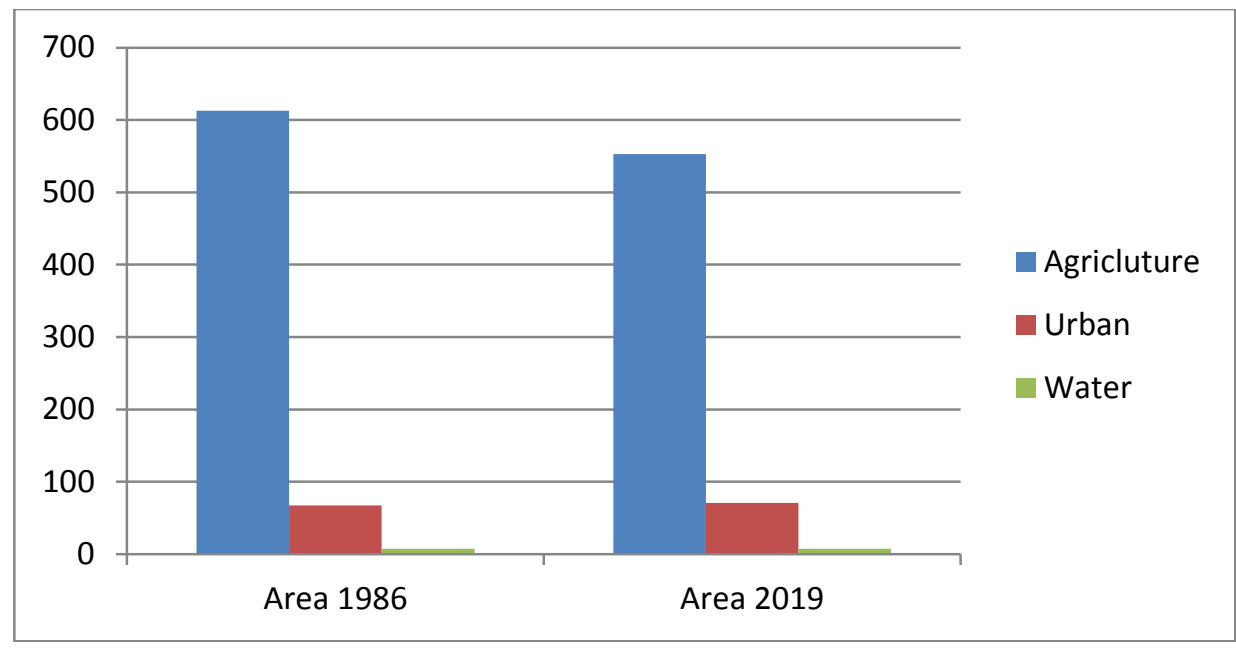

Figure 11. Change detection in land cover and urban area during the 1986 -2019 in El-Gharbiya Governorate.

\section{Conclusion}

The loss of limited arable land associated with population growth requires the transfer of new urban development plans to locations that are less important for food production. Use GIS and RS to systematically update the city database to detect new changes, which mainly depends on the frequency and rate of occurrence of urban changes and the socio-economic development of the region. Remote sensing and GIS were employed using satellite images from 1986 to 2019 to classify and analyze dramatic changes of agriculture areas and urban sprawl. It was found that the about $9.8 \%$ of the most fertility lands were lost between 1986 and 2019 due to urban encroachment by building scents ructions in El-Gharbiya Governorate, especially after the dramatic change in Egypt during 2011.According to the results of the study, the following should be taken into consideration:1) Urban Planning agency should cover preserve agricultural land from further urban encroachment to protect agriculture sector, 2) Urban Planning agency should be concerned to develop rural areas and preserve the agriculture character, which will make farmers more concern for protecting their cultivated land and 3) GIS and remote sensing proved to be efficient tools for assessing urban encroachment.

\section{References}

Abdel Rahman, M.A.E., Shalaby, A., Aboelsoud, M.H. and Moghanm, F.S. $2017 . \quad$ GIS spatial model based for determining actual land degradation status in Kafr El-Sheikh Governorate, North Nile Delta. Mod.Earth Sys. Environ. (In Press).

A Mohamed E. S., Morgun E. G. and Kovda I. V. 2011. Assessment of soil degradation in the eastern part of the Nile Delta // Moscow University Soil Science Bulletin, 66 (3 ): 86-92.
Baylis K, Jolejole M. and Lipper L. 2012. Land degradation's implications on agricultural value of production in Ethiopia: a look inside the bowl. Presentation Papers at the International Association of Agricultural Economists (IAAE) Triennial Conference, Foz do Iguacu.

El Baroudy, A.A. and Moghanm, F.S. 2014. Combined use of remote sensing and GIS for degradation risk assessment in some soils of the Northern Nile Delta, Egypt.Egypt. J. Rem. Sens. Space Sci. 17: 77-85.

El Baroudy, A. and El Baroudy, A.2011. Monitoring Land Degradation Using Remote Sensing and GIS Techniques in an Area of the Middle Nile Delta, Egypt. Catena., 87:201-208.

El-Raey, M., Nasr, S., El-Hattab, M. and Frihy, O. 1995. Change detection of Rosetta promontory over the last forty years. Int. J. Rem. Sens., 16: 825-834.

Embabi, N.S. 2018. The Nile Delta. In: Embabi, N.S. (Ed.), Landscapes and land forms of Egypt: Landforms and evolution. Springer International Publishing, Cham, pp. 57-68

Hamdi .H and Abdelhafez. S. 2001. "Agriculture and soil survey in Egypt," in Soil Resources of Southern and Eastern Mediterranean Countries, Ed. by P. Zdruli et al. (Centre International de Hautes Etudes AgronomiquesMediterraneennes, Bari, 2001), pp. 111-125. http://om.ciheam.org/om/pdf/b34/01002089.pdf.

Hazbavi, Z.; Davudirad, A.A. and Alaei, N. 2019. Overview on Land Degradation in The Industrial Shaz and Watershed; LAP LAMBERT Academic Publishing: Saarbrücken, Germany.

Johnson, D.L. and Lewis L.A. 2007. Land degradation: creation and destruction. Rowman and Littlefield, Lanham, DM, Boulder, New York, Toronto, Oxford.

Jensen, J.R. 1983. Urban/suburban land-use analysis. In: Colwell, R.N. (Ed.), In: Manual of Remote Sensing, 2. American Society 
of Photogrammetry, Falls Church, Virginia, USA, pp. 1571-1666.

Liu, Y.;Wang, J. and Deng, X. 2008. Rocky land desertification and its driving forces in the karst areas of rural Guangxi, Southwest China. J. Mt. Sci., 5, 350-357.

Mahala, A. 2017. Processes and status of land degradation in a plateau fringe region of tropical environment. Environ. Process.4, 663-682.

Martin, L.R.G. 1986. Change detection in the urban fringe emphazing land sat satellite imagery. Plan Canada 26, 182-190.

Martin, L.R.G. and Howarth, P.J. 1989. Change detection accuracy assessment using SPOT multispectral imagery of the rural-urban fringe. Rem. Sens. Environ., 30: 55-66.

Mohamed. E. S., Schu, B. and Belal, A. 2013. "Assessment of environmental hazards in the northwestern coast of Egypt using RS and GIS," Egyp t. J. Remote Sens. Space Sci., 16: 219-229.

Mohamed, N.N. 2017a. Land degradation in the Nile Delta. In: Negm, A.M. (Ed.), The Nile Delta. Springer International Publishing, Cham, pp. 235264.

Ngome, A.F.; Becker, M.; Mtei, K.M. and Mussgnug, F. 2011. Fertility management for maize cultivation in some soils.Of Western Kenya. Soil Tillage Res. 117: 69-75.

Pilon, P.G., Howarth, P.J. and Bullock, R.A. 1988. An enhanced classification approach to change detection in semi-arid environments.Photogramm. Eng. Rem. Sens., 54: 1709-1716.

Reed, M.S.; Buenemann, M.; Atlhopheng, J.; Akhtar-Schuster, M.; Bachmann, F.; Bastin, G.; Bigas, H.;Chanda, R.; Dougill, A.J. and Essahli, W. 2011. Cross-scale monitoring and assessment of land degradation andsustainable land management: A methodological framework for knowledge management. Land Degrad. Dev., 22: 261-271.

Salih, A.; Ganawa, E. and Elmahl, A. 2017. Spectral mixture analysis (SMA) and change vector analysis (CVA) methodsfor monitoring and mapping land degradation/desertification in arid and semiarid areas (Sudan), using Land sat imagery. Egypt. J. Remote Sens. Space Sci., 20: S21-S29

Sanchez, P.A.; Palm, C.A. and Buol, S.W. 2003, Fertility capability soil classification: A tool to help assess soil quality in the tropics. Geoderma,114, 157-185.

Tittonell, P.; Vanlauwe, B.; De Ridder, N.; Giller, K. 2007, Heterogeneity of crop productivity and resource use eciency within smallholder Kenyan farms: Soil fertility gradients or management intensity gradients? Agric. Syst., 94: 376-390.

UNCCD. 1994. United Nations convention to combat desertification in those countries experiencing serious drought and/or desertification, particularly in Africa. UN, Paris.

UNCCD. 2002. Global Alarm: Dust and Sandstorms from the World's Drylands, Asia Regional Coordinating Unit, Secretariat of the United Nations Convention to Combat Desertification (UNCCD-CRIC1), Bangkok.

UNCCD. 2013. Economic and Social impacts of desertification, land degradation and drought. White Paper I. UNCCD 2nd Scientific Conference of United Nations Convention to Combat Desertification, prepared with the contributions of an international group of scientists. Available from: http:// 2sc.unccd.int (accessed 26 March 2013.), Bonn, Germany.

Velmourougane, K. and Blaise, D. 2017. Soil Health, Crop Productivity and Sustainability Challenges. Sustain. Chall. Agro food Sector, 21: 509-531.

Winslow, M.; Akhtar-Schuster, M.; Martius, C.; Stringer, L.; Thomas, R. and Vogt, J. 2011. Special Issue on Understanding Dry land Degradation Trends. Land Degrad. Dev., 22: 145312.

Weinzierl, T.; Wehberg, J.; Böhner, J. and Conrad, O. 2015. Spatial Assessment of Land Degradation Risk for the Okavango River Catchment, Southern Africa Land Degrad. Dev., 27: 281-294. 
الكثف عن التغيرات في النمو الحضري في بعض المناطق في محافظة الغربية باستخدام تقتيات الاستشعار عن بعد ونظم المعلومات الجغرافية

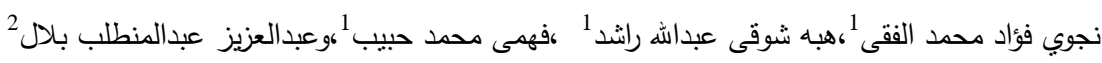

1- قسم الاراضى والمياه -كليه الزاعه-مشتهر -جامعه بنها- مصر

2- الهيئة القومية للاسنشعار عن بعد وعلوم الفضاء-القاهرة- مصر اهرياه

ويعد الزحف العمراني أحد المشاكل الرئيسية التي تحد من الأراضي الخصبة للغاية في دلتا النيل في مصر . اليوم في مصر وقد يؤدي إلى اللى

مشاكل في الأمن الغذائي. الاستشعار عن بعد ونظم المعلومات الجغرافية هي أدوات فعالة لرسم وتحليل الزحف الحضري باستخدام 3 صور لاندسات Land sat -OLI المكتسبة في عام Land sat -ETM و 1986 و المكتسبة في عام Land-TM ) ) , والتي توفر البيانات اللازمة لقياس التغير في المنطقة الحضارية للمنطقة التي خضعت للدراسة ـ الهدف من هذه الدراسة هو تقدير التغيرات في

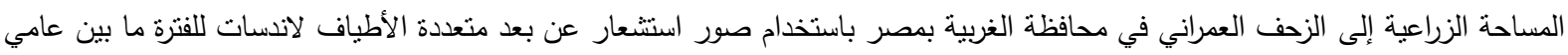
1986 و2019. تم استخدام برامج (ENVI5 land Arc GIS 10.2) لمعالجة وتحليل بيانات الاستشعار عن بعد. وقد رصدت المرئيات الفضائية التغيرات في استخدام الأراضي الغطاء الأراضي في المنطقة موضع الدراسة. تم تحديد فئتنين في المنطقة التي تمت دراستها في عامي 1986 و2019 , المنطقة الزراعية والزحف العمراني. تناقص مساحة الأراضي الزراعية بمقدار 6000 هكتار وزيادة المساحة الحضرية بمقدار 5880 هكتارا. إن التغير في أنماط الحياة البشرية وزيادة النمو السكاني في منطقة الدراسة قد عجلت من التدهور البيئي الزحف العمراني هو العمليات

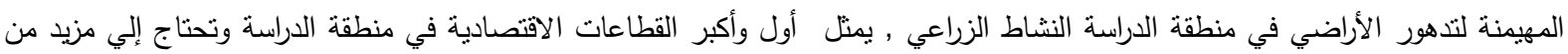

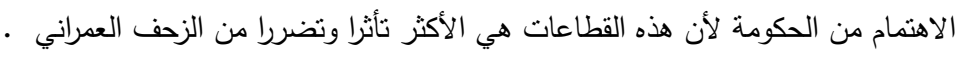

